\title{
The anti-adhesive and anti-aggregatory effects of phenolics from Trifolium species in vitro
}

\author{
Joanna Kolodziejczyk-Czepas ${ }^{1} \cdot$ Malgorzata Sieradzka $^{1} \cdot$ Barbara Wachowicz $^{1}$. \\ Pawel Nowak $^{1} \cdot$ Wieslaw Oleszek $^{2} \cdot$ Anna Stochmal $^{2}$
}

Received: 1 October 2015/Accepted: 8 December 2015/Published online: 19 December 2015

(C) The Author(s) 2015. This article is published with open access at Springerlink.com

\begin{abstract}
The present in vitro study includes a comparative evaluation of anti-platelet (anti-thrombotic) properties of plant phenolics, isolated from nine different clover (Trifolium) species. The analysis covered phenolic fractions isolated from $T$. alexandrinum L., T. fragiferum L., $T$. hybridum L., T. incarnatum L., T. pallidum Waldst et Kit., T. resupinatum $\mathrm{L}$. var. majus Boiss, T. resupinatum $\mathrm{L}$. var. resupinatum, T. scabrum L., and T. pratense L. (red clover). The inhibitory effects of plant preparations $(1-50 \mu \mathrm{g} /$ $\mathrm{ml}$ ) on hemostatic functions of blood platelets were assessed by measurements of thrombin- or ADP-induced platelet adhesion to fibrinogen, platelet aggregation in platelet-rich plasma (activated with ADP or collagen), and by the determination of PF-4 secretion from platelet $\alpha$ granules. The influence of $T$. phenolics on arachidonic cascade in blood platelets was also determined. $T$. resupinatum var. majus, $T$. resupinatum var. resupinatum, and $T$. scabrum had the strongest anti-platelet effects. These preparations displayed the most evident anti-adhesive and anti-aggregatory effects in response to all of the used agonists: thrombin $(0.2 \mathrm{U} / \mathrm{ml})$, ADP $(10 \mu \mathrm{M})$, and collagen $(2 \mu \mathrm{g} / \mathrm{ml})$, and their inhibitory properties were also confirmed by an analysis of PF-4 secretion. T. scabrum and some of other examined clover species possess significantly higher concentrations of both isoflavones and
\end{abstract}

Joanna Kolodziejczyk-Czepas

joannak@biol.uni.lodz.pl

1 Department of General Biochemistry, Faculty of Biology and Environmental Protection, University of Lodz, Pomorska 141/143, 90-236 Lodz, Poland

2 Department of Biochemistry, Institute of Soil Science and Plant Cultivation, State Research Institute, Czartoryskich 8 , 24-100 Pulawy, Poland other bioactive phenolics, when compared to red clover. The obtained results suggest that these clovers contain substances with potent anti-platelet properties.

Keywords Adhesion - Aggregation - Clover · Platelets · Trifolium

\section{Introduction}

Folk medicine recommendations have been a starting point for research on dietary supplements and new remedies for clinical use. Ethnomedicinal application of up to $80 \%$ of plant-derived drugs may be the same or similar to the current use of the active substances of those species [1]. Clovers are mostly identified as valuable forage plants; however, both $T$. pratense (the best known of Trifolium species) and other species from the Trifolium genus are characterized by a wide range of therapeutic uses in folk medicine of different world regions. Some clovers are also listed as traditional wild food [2,3]. Moreover, the latest findings suggest that edible flower extracts of $T$. pratense L. and $T$. repens $\mathrm{L}$. may be promising functional components of human diet [4]. The curative properties of red clover have been evidenced by numerous ethnomedicinal surveys as well as by in vitro and in vivo examinations [5]. Nowadays, red clover is a bioactive ingredient of numerous dietary supplements, nutraceuticals, or herbal drugs, commonly used in order to mitigate menopausal complaints. Moreover, it has been found that herbal preparations originated from this plant display the cardiovascular disease-preventive effects [6]. So far, $T$. pratense has been mainly studied in terms of isoflavone content and phytoestrogenic properties. Simultaneously, it is well known that Trifolium species are a rich source of other (poly)phenols 
that may determine biological activities of preparations from these plants. Our earlier comparative analysis of 57 Trifolium species [7] demonstrated the presence of three or four main groups of polyphenolic substances such as flavonoids, phenolic acids, and clovamides, in clover extracts.

Under physiological conditions, platelet activation and accumulation at sites of vascular injury are crucial stage of haemostasis, preventing the blood loss. On the other hand, it is also well established that the enhanced platelet activation (e.g., associated with numerous western diseases) may lead to the formation of pathogenic thrombi. Therefore, the research on natural compounds with anti-platelet and/or anticoagulation properties have been intensively developed [8]. Numerous epidemiological studies indicated the importance of diet rich in plant-derived polyphenols in the prevention of cardiovascular diseases. The disease-preventive effects of natural substances are mainly attributed to their antioxidant properties, protecting against the harmful effects of oxidative stress, which is frequently associated with occurrence of cardiovascular risk factors [9-11]. Another aspect of beneficial influence of plant substances on human health may be their ability to prevent the hyperactivation of blood platelets. The enhanced platelet activation and oxidative stress are important factors, involved in the pathogenesis of numerous cardiovascular disorders and complications of other diseases. Thus, in the prevention of Western diseases, the combination of antioxidant and antiplatelet activity of plant extract is particularly desirable from the pharmacological point of view [12-14]. For instance, both radical scavenging and anti-platelet effects were found for an ethnomedicinal plant Salvia miltiorrhiza Bunge $S$. miltiorrhiza has been used extensively in traditional medicine in China and Korea in the treatment of coronary heart disease, cerebrovascular disease, and inflammation. Scientific studies confirmed its anti-thrombotic properties, including the inhibition of ADP and collagen-induced platelet aggregation as well as thrombin-stimulated platelet adhesion to collagen or fibrinogen [15]. The inhibitory effects on platelet aggregation were also found for other plants, including Allium sativum [16], Cyperus rotundus [17], Ficus glomerata [18], and Urtica dioica [19].

The present work is based on the in vitro evaluation of anti-platelet (anti-thrombotic and cardioprotective) properties of plant preparations from nine clover Trifolium species, i.e., phenolic fractions of $T$. alexandrinum Jusl, $T$. fragiferum L., T. hybridum L., T. incarnatum L., T. pallidum Waldst et Kit., T. pratense L., T. resupinatum L. var. majus Boiss, T. resupinatum L. var. resupinatum, and $T$. scabrum L. The plant extracts were examined as possible sources of cardioprotective substances for future use in dietary supplements or herbal drugs. In previous studies, we demonstrated considerable free radical scavenging properties and antioxidant effects of the above species
[20-23]. The biological activity of clovers other than $T$. pratense and their influence on human health have been not well described yet. The existing evidence indicates the antioxidant, anti-inflammatory, anti-diabetic, and anticancer properties of some clovers [5]; however, the comparative evaluation of the anti-platelet (anti-thrombotic) actions of extracts isolated from several different species is a novel aspect of physiological effects of Trifolium-derived substances. Until recently, very few studies have been designed to define the effects of Trifolium plants on blood components, including the haemostatic system. Red clover isoflavones were found to activate synthesis of an antiplatelet factor: nitric oxide (NO), by stimulation of transcriptional pathways in endothelial cells [24]. Furthermore, Lam et al. [25] reported that isoflavones obtained from red clover might suppress inflammation.

\section{Materials and methods}

\section{Chemicals}

For measurements of platelet adhesion, the Thermo Scientific Pierce BCA Protein Assay kit (Thermo Scientific, Rockford, USA) was used. ADP and collagen were from Chrono-Log Corporation (Havertown, USA), and thrombin was purchased from BioMed Lublin, Poland. Fibrinogen was isolated from human plasma, according to the method described by Doolittle et al. [26]. All other organic and nonorganic reagents (of an analytical grade) were obtained from local commercial suppliers.

\section{Plant material}

Seeds of clover: T. alexandrinum Jusl, T. fragiferum L., T. hybridum L., T. incarnatum L., T. pallidum et Kit., T. pretense L., T. resupinatum L. var. majus Boiss, T. resupinatum L. var. resupinatum, and $T$. scabrum L. derived from the genebank, Zentralinstitute für Pflanzengenetik und Kulturpflanzenforschung (Gatersleben, Germany) were sown on experimental plots of the Institute of Soil Science and Plant Cultivation in Pulawy, Poland. The herbarium voucher numbers are as follows, respectively: TRIF 30/79, TRIF 37/83, TRIF 6/82, TRIF 82/83, TRIF 253/95, TRIF 186/75, TRIF $81 / 83$, TRIF $43 / 80$, and TRIF $120 / 79$. Above-ground parts of plants were collected at the beginning of flowering, frozen, freeze-dried, ground, and used in the preparation of extracts.

\section{Extraction and fractionation of extracts}

Each of the nine Trifolium species was extracted according to the method previously described, consisting in maceration of the plant material with an aqueous solution of 
methanol $(80 \%(\mathrm{v} / \mathrm{v}) \mathrm{MeOH})$ at room temperature for $24 \mathrm{~h}$ [27]. After low-pressure evaporation, extracts were fractionated in accordance with method of Stochmal et al. [27]. In short, the extract was dissolved in water and was applied to a short preparative column packed with reversed-phase C18 package. First, in order to remove sugars, the column was washed with water and then using $40 \% \mathrm{MeOH}$, phenolic fraction was eluted, which contained phenolic acids, flavonoids, isoflavones, and clovamides. The quantitative content of these compounds was determined by UPLC with photodiode array detector (PDA) [7], and the results are shown in Table 1.

\section{Isolation of blood platelets and preparation of the examined samples}

Blood from healthy volunteers was purchased from the Regional Centre of Blood Donation and Blood Treatment in Lodz, Poland. All experiments were approved by the committee on the Ethics of Research at the University of Lodz (KBBN-UL/II/18/2012).

Platelet-rich plasma (PRP) and blood platelets were isolated by differential centrifugation of blood [28]. The sedimented platelets were then suspended in the Tyrode's buffer; the amount platelets were estimated spectrophotometrically, accordingly to the method of Walkowiak et al. [29]. For adhesion measurements, 1.8-2.2 $\times 10^{8}$ platelets/ $\mathrm{ml}$ were used, while the determination of malondialdehyde (MDA) was performed with the use of $5 \times 10^{8}$ of platelets/ $\mathrm{ml}$. The stock solutions of Trifolium $(10-20 \mathrm{mg} / \mathrm{ml})$ phenolic fractions were prepared in 20 or $30 \%$ DMSO. The preliminary measurements of the activity of native platelets and platelets treated with DMSO at concentrations corresponding to those added with Trifolium phenolic fractions revealed that DMSO itself had no effect. However, in order to maintain the same experimental conditions, DMSO was added to all control samples. Thus, activities of platelets pre-incubated with Trifolium fractions were compared to the DMSO-containing controls. Samples were pre-incubated with the examined Trifolium preparations (at the final concentrations of $1-50 \mu \mathrm{g} / \mathrm{ml}$ ), for $15 \mathrm{~min}$ at $37^{\circ} \mathrm{C}$, and subsequently used for experiments.

\section{Platelet adhesion}

Adhesion of blood platelets to fibrinogen $(0.1 \mathrm{mg} / \mathrm{ml})$ was determined by a static method, according to Tuszynski and Murphy [30]. A 96-well, flat-bottom microplates were coated with $100 \mu \mathrm{l}$ of adhesive protein suspension (fibrinogen) for overnight, at $4{ }^{\circ} \mathrm{C}$. Then, the nonadsorbed protein was removed by three-time washing with $250 \mu \mathrm{l}$ of $0.1 \mathrm{M}$ TBS buffer. Then, $200 \mu \mathrm{l}$ of $1 \%$ BSA (a heat-shock fraction) in TBS was added to each well. The microtiter plates were incubated for $2 \mathrm{~h}$ at $37{ }^{\circ} \mathrm{C}$. The BSA remnants were then removed by three-time washing with $250 \mu \mathrm{l}$ of TBS. The platelet suspensions (100 $\mu$ l of DMSO-containing control or samples pre-incubated with the Trifolium preparations) were added into the wells. Immediately, $50 \mu \mathrm{l}$ of the agonist was added to the wells (to obtain the final concentration of $10 \mu \mathrm{M}$ for $\mathrm{ADP}$ and $0.2 \mathrm{U} / \mathrm{ml}$ for thrombin, respectively). After an hour of incubation at $37{ }^{\circ} \mathrm{C}$, the non-adherent platelets were removed by threetime washing with TBS, and then, $200 \mu$ of the BCA mixture was added. After $60 \mathrm{~min}$ incubation at $37^{\circ} \mathrm{C}$, the absorbance at $560 \mathrm{~nm}$ was measured.

\section{Platelet aggregation}

Platelet aggregation was measured in PRP, using the Chrono-Log 490 aggregometer. PRP samples were preincubated of $15 \mathrm{~min}$ at $37^{\circ} \mathrm{C}$ with the examined Trifolium preparations and transferred into aggregometer cuvettes.

Table 1 The phytochemical characterization of the examined phenolic fractions isolated from aerial parts of nine Trifolium species [22, 23]

\begin{tabular}{|c|c|c|c|c|c|}
\hline \multirow[t]{2}{*}{ Trifolium species } & \multicolumn{5}{|c|}{ Concentration (mg/g of dry mass) } \\
\hline & $\begin{array}{l}\text { Total } \\
\text { phenolic } \\
\text { content }\end{array}$ & Clovamides & Flavonoids & Isoflavones & $\begin{array}{l}\text { Phenolic } \\
\text { acids }\end{array}$ \\
\hline T. alexandrinum & 52.55 & 9.63 & 22.30 & 18.97 & 1.65 \\
\hline T. hybridum & 15.24 & 0.44 & 5.22 & - & 9.58 \\
\hline T. fragiferum & 11.30 & - & 5.18 & 5.50 & 0.62 \\
\hline T. incarnatum & 47.97 & - & 41.54 & 5.10 & 1.32 \\
\hline T. pallidum & 35.06 & 12.94 & 0.61 & 7.31 & 14.20 \\
\hline T. resupinatum var. resupinatum & 17.32 & - & 11.25 & 5.21 & 0.86 \\
\hline T. resupinatum var. majus & 22.54 & - & 9.76 & 11.17 & 1.61 \\
\hline T. scabrum & 80.93 & - & 7.67 & 72.76 & 0.66 \\
\hline T. pratense & 14.82 & - & 3.89 & 5.01 & 5.92 \\
\hline
\end{tabular}


Platelet aggregation was induced by ADP (at the final conc of $10 \mu \mathrm{M}$ ) or collagen (at the final conc of $2 \mu \mathrm{g} / \mathrm{ml}$ ).

\section{Platelet factor 4 secretion}

The procedure was performed using of the RayBiotech $(C)$ Human PF-4 ELISA kit. The secretion of PF-4 was monitored in PRP, after stimulation by ADP $(10 \mu \mathrm{M}$, final conc) or collagen $(0.2 \mu \mathrm{g} / \mathrm{ml}$, final conc). PRP samples (control and pre-incubated with the examined phenolic fractions) were activated by the agonists $\left(10 \mathrm{~min}, 37^{\circ} \mathrm{C}\right)$, and then, immediately centrifuged in order to remove blood platelets. Before the PF-4 immunodetection, platelet poor plasma (PPP) was diluted 200 times with phosphate buffered saline.

\section{Arachidonic acid metabolism-measurements of MDA generation}

To $0.5 \mathrm{ml}$ of platelet suspensions $\left(5 \times 10^{8} \mathrm{ml}\right)$, in Tyrodes's buffer, thrombin was added to the final conc of $0.4 \mathrm{U} / \mathrm{ml}$. After $5 \mathrm{~min}$ of incubation, equal volumes of trichloroacetic acid $(15 \%$, in $0.25 \mathrm{M} \mathrm{HCl})$ and thiobarbituric acid $(0.37 \%$, in $0.25 \mathrm{M} \mathrm{HCl})$ were added. After 2 min of vigorous shaking, the samples were boiled for 10 min, cooled, and centrifuged in order to sediment the platelet pellet. A clear supernatant was collected. Colorimetric measurements were performed at $\lambda=535 \mathrm{~nm}$. The concentration of MDA was calculated from the molar absorption coefficient for the thiobarbituric acid-reactive substances $\left(\varepsilon=156000 \mathrm{M}^{-1} \times \mathrm{cm}^{-1}\right)$ [31].

\section{Statistical analysis}

The first step of statistical analysis was the elimination of the uncertain data by the $Q$-Dixon test. All the values in this work are expressed as mean $\pm \mathrm{SEM} ; p$ values $<0.05$ are considered to be statistically significant; $n=$ number of blood donors (at least two independent pre-incubations of clover extracts with blood platelets or PRP from each donor were performed). The used tests are indicated in figure legend and table captures.

\section{Results}

In the first stage of the study, effects of the examined Trifolium preparations $(1,5$, and $50 \mu \mathrm{g} / \mathrm{ml})$ on platelet adhesion (stimulated by thrombin or ADP) were assessed (Table 2). Measurements of thrombin-induced adhesion of isolated platelets revealed the most evident inhibitory effect of phenolic fractions of $T$. incarnatum, $T$. resupinatum var. majus, and T. scabrum. During evaluations of platelet response to $10 \mu \mathrm{M}$ ADP, the phenolics of T. incarnatum, T. resupinatum var. majus, T. scabrum as well as $T$. pratense displayed significantly higher anti-adhesive effects.

The next part of this work included determination of abilities of Trifolium preparations (1 and $5 \mu \mathrm{g} / \mathrm{ml}$ ) to inhibit platelet aggregation (Fig. 1a, b). At this stage, platelet response to agonists (ADP and collagen) was assessed in PRP. After the stimulation with ADP, the most potent inhibitor of platelet aggregation was the phenolic fraction of $T$. resupinatum var. resupinatum. The aggregation of blood platelets was also significantly reduced by preparations of $T$. resupinatum var. majus, T. scabrum, and $T$. alexandrinum (1-5 $\mu \mathrm{g} / \mathrm{ml})$. Anti-platelet actions of $T$. fragiferum and T. pallidum were slightly weaker, while for T. hybridum, T. incarnatum, and T. pratense, no statistically significant inhibition was found (Fig. 1a). In experiments with the collagen-induced platelet aggregation, inhibitory actions of the examined Trifolium species were comparable, except the preparations of $T$. alexandrinum and $T$. incarnatum, which had no anti-platelet effects in this assay (Fig. 1b).

After comparison of the anti-adhesive and anti-aggregatory effects of the examined Trifolium preparations, the additional measurements of collagen or ADP-induced PF-4 secretion from platelet $\alpha$ granules were performed with only one, selected concentration of the Trifolium preparations $(5 \mu \mathrm{g} / \mathrm{ml})$. These experiments revealed some differences between anti-platelet actions of the examined clover species (Table 3). Determination of the ADP-induced secretion of PF-4 confirmed anti-platelet properties of $T$. scabrum, which were also observed in platelet aggregation measurements. Additionally, this assay showed the inhibitory effect of $T$. pratense, which was not detected during platelet aggregation. The reduction of PF-4 release from platelets in the presence of $T$. resupinatum var. resupinatum, $T$. resupinatum var. majus, and $T$. pallidum phenolics was also observed; however, it was statistically insignificant. Furthermore, some inhibitory effects were recorded for samples treated with phenolic fractions of $T$. resupinatum var. resupinatum, T. resupinatum var. majus, T. scabrum, and T. pallidum in the measurements of the collagen-induced PF-4 release, but the statistical significance of these differences was not found (Table 3).

Furthermore, the analysis of MDA formation from $\mathrm{PGH}_{2}$ in platelets stimulated by thrombin revealed a statistically significant inhibition of platelet secretory process in samples treated with phenolic fractions of $T$. alexandrinum, T. hybridum, T. incarnatum, T. pallidum, and $T$. pratense. These findings indicate that the examined phenolic fractions may interfere with arachidonic acid cascade (Table 4). 
Table 2 The inhibitory effects of phenolic fractions of nine Trifolium species on blood platelet adhesion to fibrinogen in vitro

\begin{tabular}{|c|c|c|c|}
\hline \multirow[t]{2}{*}{ Trifolium species } & \multirow{2}{*}{$\begin{array}{l}\text { Concentration } \\
(\mu \mathrm{g} / \mathrm{ml})\end{array}$} & \multicolumn{2}{|c|}{ Platelet adhesion to fibrinogen (\%) } \\
\hline & & $\begin{array}{l}\text { Platelets stimulated with } \\
\text { thrombin }(0.2 \mathrm{U} / \mathrm{ml})\end{array}$ & $\begin{array}{l}\text { Platelets stimulated with } \\
\text { ADP }(10 \mu \mathrm{M})\end{array}$ \\
\hline Control (untreated) platelets & 0 & $100 \pm 7.06$ & $100 \pm 3.08$ \\
\hline \multirow[t]{3}{*}{ T. alexandrinum } & 1 & $93.00 \pm 5.57$ & $87.14 \pm 1.98$ \\
\hline & 5 & $85.61 \pm 5.11$ & $89.73 \pm 3.56$ \\
\hline & 50 & $85.56 \pm 3.77$ & $83.96 \pm 2.75^{*}$ \\
\hline \multirow[t]{3}{*}{ T. hybridum } & 1 & $86.96 \pm 4.25$ & $88.36 \pm 2.43$ \\
\hline & 5 & $85.81 \pm 4.73$ & $88.37 \pm 1.81$ \\
\hline & 50 & $88.99 \pm 4.77$ & $88.55 \pm 2.61$ \\
\hline \multirow[t]{3}{*}{ T. fragiferum } & 1 & $90.40 \pm 4.26$ & $89.90 \pm 3.62$ \\
\hline & 5 & $92.16 \pm 4.47$ & $90.32 \pm 3.56$ \\
\hline & 50 & $86.70 \pm 4.93$ & $82.49 \pm 1.72^{* *}$ \\
\hline \multirow[t]{3}{*}{ T. incarnatum } & 1 & $83.48 \pm 4.06$ & $80.87 \pm 2.53^{*}$ \\
\hline & 5 & $84.12 \pm 5.57^{*}$ & $76.38 \pm 3.99^{* * *}$ \\
\hline & 50 & $73.27 \pm 4.38^{* *}$ & $77.82 \pm 1.86^{* * *}$ \\
\hline \multirow[t]{3}{*}{ T. pallidum } & 1 & $80.89 \pm 4.47^{*}$ & $85.16 \pm 4.49^{*}$ \\
\hline & 5 & $76.36 \pm 4.28^{*}$ & $87.26 \pm 3.19$ \\
\hline & 50 & $84.19 \pm 4.05$ & $87.70 \pm 3.36$ \\
\hline \multirow[t]{3}{*}{ T. resupinatum var. resupinatum } & 1 & $86.07 \pm 5.02$ & $84.48 \pm 4.11^{*}$ \\
\hline & 5 & $90.29 \pm 4.78$ & $85.63 \pm 3.80^{*}$ \\
\hline & 50 & $80.30 \pm 4.88^{*}$ & $80.25 \pm 2.37^{* * *}$ \\
\hline \multirow[t]{3}{*}{ T. resupinatum var. majus } & 1 & $81.25 \pm 4.56$ & $77.42 \pm 4.21^{* * *}$ \\
\hline & 5 & $75.65 \pm 3.54^{* *}$ & $73.99 \pm 2.88^{* * *}$ \\
\hline & 50 & $78.46 \pm 6.27^{* *}$ & $75.00 \pm 2.88^{* * *}$ \\
\hline \multirow[t]{3}{*}{ T. scabrum } & 1 & $71.28 \pm 4.32^{* * *}$ & $83.04 \pm 4.99^{* *}$ \\
\hline & 5 & $76.76 \pm 4.86^{* *}$ & $80.43 \pm 4.57^{* *}$ \\
\hline & 50 & $83.77 \pm 3.89$ & $81.74 \pm 3.70^{* *}$ \\
\hline \multirow[t]{3}{*}{ T. pratense } & 1 & $90.72 \pm 3.05$ & $79.93 \pm 3.10^{* * *}$ \\
\hline & 5 & $84.40 \pm 3.43$ & $82.18 \pm 3.76^{* *}$ \\
\hline & 50 & $81.21 \pm 4.48$ & $80.36 \pm 2.90^{* * * *}$ \\
\hline
\end{tabular}

The anti-adhesive actions of Trifolium phenolics were assessed in comparison to the control (untreated) platelets, which adhesion was assumed as $100 \%$ \% $p<0.05, * * p<0.01, * * * p<0.001$, as evaluated by the Dunnett test; $n=10-12$

\section{Discussion}

Our previous studies showed that Trifolium-derived plant extracts might display considerable antioxidant and free radical scavenging properties [20-23]. Besides the antioxidative action, the preliminary experiments on $T$. pallidum and T. scabrum $(12.5-50 \mu \mathrm{g} / \mathrm{ml})$ also suggested the possible inhibitory action of some clovers on platelet activation [32]. Therefore, in the present work, we extended our in vitro studies and analyzed the anti-platelet actions of phenolic fractions of nine clover species, with particular attention on the efficacy of lower concentrations of these preparations $(1-5 \mu \mathrm{g} / \mathrm{ml})$. The first step of our studies was to determine the anti-adhesive properties of the examined clovers with the use of different platelet agonists (ADP and thrombin) and fibrinogen as the adhesive surface, in an experimental system of isolated blood platelets. These variants allowed the comparative examination of the influence of plant extracts on the mechanisms of blood platelet adhesion. The adhesion of blood platelets to fibrinogen occurs via $\alpha_{\mathrm{II}} \beta_{3}$ integrin receptor. On resting platelets, $\alpha_{\mathrm{IIb}} \beta_{3}$ receptors are maintained in a low-affinity state, but during platelet activation, these receptors are rapidly transformed into a high-affinity conformation. Platelet response to ADP is mediated by its interactions with the $\mathrm{G}$ protein-linked $\mathrm{P} 2$ receptors ( $\mathrm{P} 2 \mathrm{Y} 1$ and $\mathrm{P} 2 \mathrm{Y} 12$ ). Interaction of ADP with $\mathrm{P} 2 \mathrm{Y} 1$ receptor, linked to $\mathrm{G}_{\mathrm{q}}$, triggers the activation of phospholipase $\mathrm{C}(\mathrm{PLC}), \mathrm{Ca}^{2+}$ 


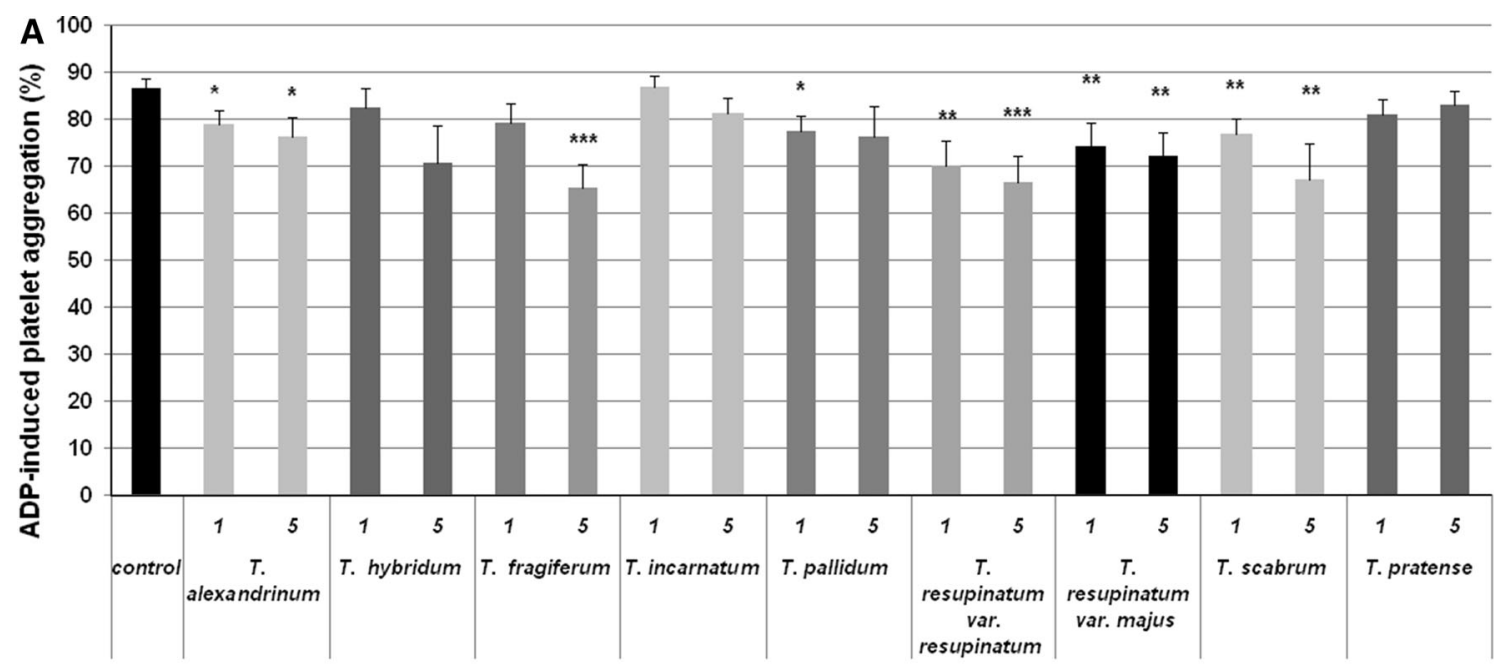

Trifolium phenolic fractions $[\mu \mathrm{g} / \mathrm{ml}]$

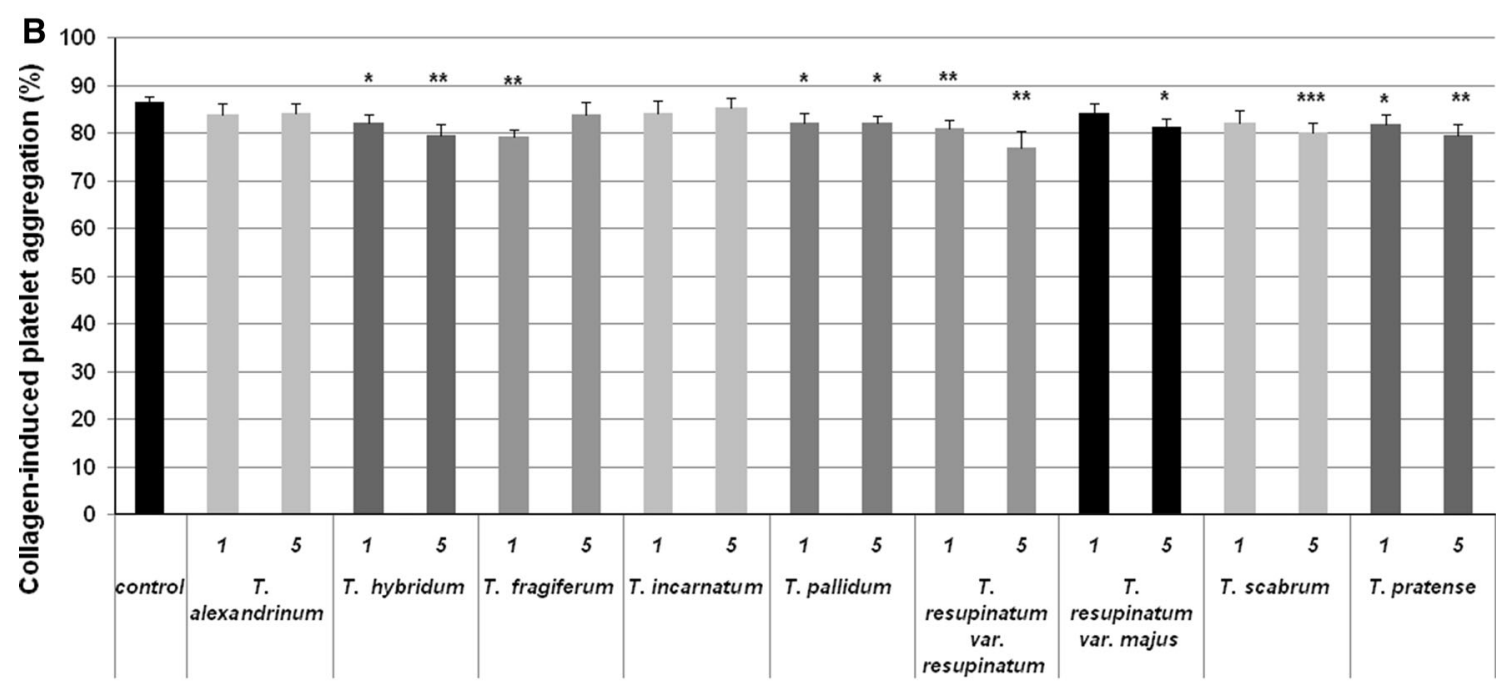

Trifolium phenolic fractions $[\mu \mathrm{g} / \mathrm{ml}]$

Fig. 1 Anti-aggregatory properties of phenolic fractions isolated from nine Trifolium species. Platelet aggregation was measured in PRP, after stimulation by ADP $(10 \mu \mathrm{M}$; panel A) or collagen $(2 \mu \mathrm{g} /$

influx as well as mobilization of intracellular $\mathrm{Ca}^{2+}$. P2Y12, which is linked to $\mathrm{Gi}$, leads to the inhibition of adenyl cyclase and decreases the cAMP level. The P2Y12 receptor is a target for several antagonists, used as anti-thrombotic/ anti-platelet agents such as clopidogrel, prasugrel, ticagrelor, cangrelor, and elinogrel. Thrombin induces platelet activation due to protease-activated receptors (PARs): PAR-1 and PAR-4. The PARs are coupled to $\mathrm{G}_{q}$ protein, transmitting cellular signals mainly by stimulation of PLC $\beta$ [33-35].

The evaluation of anti-adhesive effects of Trifolium phenolic fractions indicated that $T$. incarnatum, $T$. resupinatum var. majus, and $T$. scabrum possess the strongest inhibitory effects on thrombin-induced adhesion $\mathrm{ml}$; panel B); $* p<0.05, * * p<0.01, * * * p<0.001$, as evaluated by the $t$-Student's or Wilcoxon tests; $n=8$

to fibrinogen, contrary to the other preparations. Phenolic fractions of the remaining Trifolium species had little or no effects under those experimental conditions. Furthermore, phenolic fractions of the same Trifolium species as well as the preparation of $T$. resupinatum var. resupinatum were able to diminish platelet adhesion induced by ADP. Additionally, in experiments with ADP as an agonist, a statistically significant inhibition of platelet adhesion was also found for $T$. pratense.

Measurements of platelet adhesion in the presence of the Trifolium preparations were performed with the use of isolated human platelets, in a limited milieu. Therefore, the next analyses were conducted in PRP, in order to estimate clover effects under a more physiological environment. 
Table 3 Evaluation of inhibitory action of phenolic fractions from nine Trifolium species on platelet factor 4 (PF-4) secretion in vitro $(n=8$ and $n=6$ for ADP and collagen, respectively

\begin{tabular}{lll}
\hline $\begin{array}{l}\text { Trifolium species } \\
{[5 \mu \mathrm{g} / \mathrm{ml}]}\end{array}$ & $\begin{array}{l}\text { ADP-induced secretion } \\
\text { of PF-4 [ng/ml] }\end{array}$ & $\begin{array}{l}\text { Collagen-induced } \\
\text { secretion of PF-4 [ng/ml] }\end{array}$ \\
\hline -Control platelets & $185.522 \pm 43.434$ & $360.697 \pm 78.792$ \\
T. alexandrinum & $195.885 \pm 45.266$ & $331.368 \pm 76.012$ \\
T. hybridum & $212.905 \pm 45.229$ & $334.229 \pm 74.290$ \\
T. fragiferum & $180.445 \pm 34.190$ & $346.132 \pm 62.437$ \\
T. incarnatum & $156.345 \pm 28.480$ & $294.535 \pm 33.036$ \\
T. pallidum & $125.513 \pm 21.196$ & $315.051 \pm 42.761$ \\
T. resupinatum var. resupinatum & $124.997 \pm 26.417$ & $249.117 \pm 51.367$ \\
T. resupinatum var. majus & $156.472 \pm 26.929$ & $252.156 \pm 33.623$ \\
T. scabrum & $132.423 \pm 22.464^{*}$ & $271.010 \pm 35.424$ \\
T. pratense & $117.140 \pm 16.849^{*}$ & $263.485 \pm 33.555$ \\
\hline
\end{tabular}

$* p<0.05$, as evaluated by the Dunnett and $t$-Student's tests)

Table 4 Effects of phenolic fractions of nine Trifolium species on malondialdehyde (MDA) generation in blood platelets stimulated with thrombin $(0.4 \mathrm{U} / \mathrm{ml})$ in vitro

\begin{tabular}{ll}
\hline $\begin{array}{l}\text { Trifolium } \text { species } \\
{[5 \mu \mathrm{g} / \mathrm{ml}]}\end{array}$ & $\begin{array}{l}\text { MDA generation [nmol/ml } \\
\text { of } 2 \times 10^{8} \text { of platelets] }\end{array}$ \\
\hline Control platelets & $0.452 \pm 0.043$ \\
T. alexandrinum & $0.326 \pm 0.023^{* *}$ \\
T. hybridum & $0.374 \pm 0.046^{* *}$ \\
T. fragiferum & $0.398 \pm 0.034$ \\
T. incarnatum & $0.384 \pm 0.026^{*}$ \\
T. pallidum & $0.405 \pm 0.032^{*}$ \\
T. resupinatum var. resupinatum & $0.415 \pm 0.033$ \\
T. resupinatum var. majus & $0.410 \pm 0.030$ \\
T. scabrum & $0.379 \pm 0.059$ \\
T. pratense & $0.371 \pm 0.023^{* *}$ \\
\hline$(n=7 ; * p<0.05, * * p<0.01$, as evaluated by the Dunnett and $t$-Student's tests $)$
\end{tabular}

Both the platelet aggregometry and monitoring of platelet $\alpha$-granules secretion process (PF-4 release) were performed using ADP or collagen as platelet agonists. The incorporation of collagen into experimental system enabled the evaluation of inhibitory effects of the examined phenolic fractions on platelet activation, occurring via specific platelet receptors for this protein. Blood platelets express several collagen receptors; the integrin receptor $\alpha 2 \beta 1$ is crucial for platelet adhesion to collagen surface, while GPVI and GPIb-IX-V are required for collagen-induced platelet activation $[35,36]$. In this study, the ADP-induced platelet aggregation was inhibited by phenolic fraction of T. resupinatum var. resupinatum with the most efficacy; however, considerable inhibitory effects were also found for $T$. alexandrinum, $T$. resupinatum var. majus, and $T$. scabrum and, in some minor extent, for T. fragiferum and T. pallidum. The anti-platelet properties of $T$. scabrum were additionally confirmed by the determination of ADPinduced PF-4 secretion from platelet $\alpha$-granules. Although some tendency seemed to be evident, the decline of PF-4 release in the presence of $T$. resupinatum var. resupinatum, $T$. resupinatum var. majus, and $T$. pallidum phenolics was statistically insignificant. On the other hand, the measurements of collagen-induced platelet aggregation demonstrated comparable inhibitory effects of the examined phenolic fractions, except the $T$. alexandrinum and $T$. incarnatum, which had no significant influence. Experiments with the collagen-induced PF-4 secretion from platelets revealed some inhibitory effects of $T$. resupinatum var. resupinatum, T. resupinatum var. majus, T. scabrum, and $T$. pallidum; however, the statistical significances of these differences were not found.

A general analysis of the obtained results indicates that phenolic fractions of $T$. resupinatum var. majus, $T$. resupinatum var. resupinatum, and $T$. scabrum displayed the strongest anti-platelet properties. Among all the tested preparations, the phenolic fraction of $T$. scabrum had the highest total phenolic content ( $80.93 \mathrm{mg} / \mathrm{g}$ of dry mass), 
including $72.76 \mathrm{mg} / \mathrm{g}$ of dry mass of isoflavones (which was the highest concentration of these substances as well). The preparations of $T$. resupinatum var. resupinatum and $T$. resupinatum var. majus were characterized by lower total phenolic content-17.32 and $22.54 \mathrm{mg} / \mathrm{g}$ of dry mass, respectively. However, the phenolic fraction of $T$. resupinatum var. majus contained (over two fold) higher concentration of isoflavones $(11.17 \mathrm{mg} / \mathrm{g}$ of dry mass) when compared to the $T$. resupinatum var. resupinatum preparation $(5.21 \mathrm{mg} / \mathrm{g}$ of dry mass). It is very likely that the presence of isoflavones significantly contributes to the anti-platelet action of these plant preparations. Although the role of isoflavones in modulation of blood platelet response has been little investigated, some evidence is available. Genistein and daidzein are able to inhibit the collagen-induced platelet aggregation in vitro [37]. Furthermore, Navarro-Núñez et al. [38] demonstrated that genistein might inhibit the platelet activation induced by thrombin. According to those authors, the anti-platelet action of genistein is a result of interfering with intracellular signaling and changes in calcium mobilization, but not an effect of interactions with thrombin receptors. It has been also shown that aglycones of soy isoflavones and equol are capable of binding to thromboxane $\mathrm{A}_{2}$ receptor in human platelets [39]. 8-Prenylnaringenin (an isoflavone derivative) possesses both anti-aggregatory and anti-adhesive effects on human platelets, independently on its interaction with estrogen receptors. It has been demonstrated that 8-prenylnaringenin is able to inhibit the phosphorylation of kinases such as Pyk2, Akt, and ERK1/2. The 8-prenylnaringenin-induced modulation of platelet response to agonists included inhibitory effect on ATP release from platelet dense granules as well as suppression of cytoplasmic $\mathrm{Ca}^{2+}$ mobilization [40].

On the other hand, the preparation from T. alexandrinum, containing much higher concentration of isoflavones (18.97 mg/g of dry mass) than phenolic fractions of $T$. resupinatum var. majus and $T$. resupinatum var. resupinatum, was less effective inhibitor of platelet activation of ADP- or thrombin-induced platelet adhesion, as well as in measurements of platelet aggregation and PF-4 secretion. These findings suggest an important role of other phenolic components, such as phenolic acids and different flavonoids that are present in the examined preparations from Trifolium species. According to the literature, numerous natural polyphenolic compounds display anti-platelet properties. For instance, caffeic acid may inhibit the collagen-induced aggregation of blood platelets. It is also able to reduce the generation of thromboxane $\mathrm{A}_{2}$, a physiological autocrine platelet agonist. Molecular mechanisms of this suppression involve the inhibition of $\mathrm{Ca}^{2+}$ mobilization, being a result of the cAMP-dependent phosphorylation of inositol-1,4,5trisphosphate receptor [41]. The inhibitory effect on collagen-stimulated platelet functions was also found for quercetin, which may suppress activity of the Fyn kinase and phosphorylation of syk tyrosine kinase, and halt the PLC $\gamma 2$ signaling [42]. Furthermore, three of the examined cloverderived preparations (of $T$. alexandrinum, T. hybridum, and T. pallidum) contained clovamides, an interesting group of caffeic acid derivatives. The presence of clovamide-type polyphenols was detected only in several plant genera, and clovers seem to be the most abundant source of these substances. Results from animal study indicated that clovamide (N-caffeoyldopamine) isolated from Theobroma cacao effectively reduced the expression of P-selectin and plateletleukocyte interactions [43]. In our study, all of these three clovers displayed the inhibitory effect on thrombin-induced generation of MDA (Table 4), a marker of activation of arachidonic acid cascade, playing an important role in both the platelet activation and inflammatory processes. The decrease of MDA level was also found in platelets preincubated with phenolic fraction of $T$. pratense, which may confirm the anti-inflammatory action of this plant. The modulation of arachidonic acid pathway was previously reported in vitro by Lam et al. [25], who demonstrated the inhibitory effect of red clover isoflavones on COX-2 activity in murine and human monocyte/macrophage experimental systems.

The current knowledge of pharmacological activity of Trifolium plants is incomplete. Besides several reports containing studies on one or two clovers [44, 45], evaluation of wound healing properties of 13 clover species [46] and our previous examinations of antioxidant action of clovers, there is a lack of more extensive analysis covering at least several Trifolium species. In this in vitro study, for the first time, we evaluated and compared anti-platelet properties of nine Trifolium species, at concentration range, which may be partly relevant to the physiological conditions. Our experiments have demonstrated that the examined clovers display considerable inhibitory effects at the concentrations of $1-5 \mu \mathrm{g} / \mathrm{ml}$. The plasma concentration of different plant-derived polyphenols is estimated at a range up to $3 \mu \mathrm{mol} / \mathrm{l}$, or even about $4 \mu \mathrm{mol} / \mathrm{l}$ for some substances such as genistein, genistin, and gallic acid [47]. Studies on bioavailability of red clover isoflavones revealed that a single dose of dietary supplement, containing $38.8 \mathrm{mg}$ of isoflavones yields the following plasma concentrations of these compounds: $0.35 \mu \mathrm{M}$ for irilone, $0.39 \mu \mathrm{M}$ for daidzein, and $0.06 \mu \mathrm{M}$ for genistein [48].

\section{Conclusions}

In conclusion, this work is the first comparative evaluation of anti-platelet properties of nine Trifolium species. Our studies revealed that the phenolic fractions of $T$. scabrum, 
T. resupinatum var. resupinatum, and $T$. resupinatum var. majus seem to be the most effective inhibitors of platelet activation; however, anti-platelet effects (in a minor extent) were also found for other of the examined species. The obtained results may be a base for further studies on clovers as a source of extracts with anti-platelet properties.

Acknowledgments The authors would like to thank Ms. Magdalena Mizera, M.Sc, for her very helpful technical assistance in experiments on platelet adhesion. Special thanks go to Michal B. Ponczek, Ph.d, and Michal Bijak, Ph.d (Department of General Biochemistry, University of Lodz) for their suggestions concerning the statistical analysis. This work was supported by Grant No. 506/1136 (University of Lodz, Poland) and seventh Framework Program of European Community, OSCAR (Contract No. FP7-KBBE-2011-5-289277).

\section{Compliance with ethical standards}

Conflict of interest The authors declare that they have no conflict of interest.

Open Access This article is distributed under the terms of the Creative Commons Attribution 4.0 International License (http://creative commons.org/licenses/by/4.0/), which permits unrestricted use, distribution, and reproduction in any medium, provided you give appropriate credit to the original author(s) and the source, provide a link to the Creative Commons license, and indicate if changes were made.

\section{References}

1. Fabricant DS, Farnsworth NR (2001) The value of plants used in traditional medicine for drug discovery. Environ Health Perspect 109:69-75

2. Łuczaj $€$ (2012) Ethnobotanical review of wild edible plants of Slovakia. Acta Soc Bot Pol 81:245-255

3. Sansanelli S, Tassoni A (2014) Wild food plants traditionally consumed in the area of Bologna (Emilia Romagna region, Italy). J Ethnobiol Ethnomed 10:69

4. Tundis R, Marrelli M, Conforti F, Tenuta MC, Bonesi M, Menichini F, Loizzo MR (2015) Trifolium pratense and T. repens (Leguminosae): edible flower extracts as functional ingredients. Foods 4:338-348

5. Kolodziejczyk-Czepas J (2012) Trifolium species-derived substances and extracts-biological activity and prospects for medicinal applications. J Ethnopharmacol 143:14-23

6. Asgary S, Moshtaghian J, Naderi G, Fatahi Z, Hosseini M, Dashti G, Adibi S (2007) Effects of dietary red clover on blood factors and cardiovascular fatty streak formation in hypercholesterolemic rabbits. Phytother Res 21:768-770

7. Oleszek W, Stochmal A, Janda B (2007) Concentration of isoflavones and other phenolics in the aerial parts of Trifolium species. J Agric Food Chem 55:8095-8100

8. Vilahur G, Badimon L (2013) Antiplatelet properties of natural products. Vasc Pharmacol 59:67-75

9. Soory M (2002) Nutritional antioxidants and their applications in cardiometabolic diseases. Infect Disord Drug Targets 12:388-401

10. Kozłowska A, Szostak-Wegierek D (2014) Flavonoids-food sources and health benefits. Rocz Panstw Zakl Hig 65:79-85

11. Papageorgiou N, Tousoulis D, Katsargyris A, Charakida M, Androulakis E, Siasos G, Tentolouris C, Stefanadis C (2013) Antioxidant treatment and endothelial dysfunction: is it time for flavonoids. Recent Pat Cardiovasc Drug Discov 8:81-92
12. Bachmair EM, Ostertag LM, Zhang X, de Roos B (2014) Dietary manipulation of platelet function. Pharmacol Ther 144:97-113

13. Santhakuma AB, Bulmer AC, Singh I (2014) A review of the mechanisms and effectiveness of dietary polyphenols in reducing oxidative stress and thrombotic risk. J Hum Nutr Diet 27:1-21

14. Zordoky BN, Robertson IM, Dyck JR (2015) Preclinical and clinical evidence for the role of resveratrol in the treatment of cardiovascular diseases. Biochim Biophys Acta 1852:1155-1177

15. Yang S-A, Im N-K, Ji Y-J, Yoo D-C, Jhee K-H, Lee I-S (2008) Radical scavenging and inhibition of platelet function by a polyphenol-rich fraction from Salvia miltiorrhiza Bunge. Open Nat Prod J 1:7-13

16. Ansari F, Soltan NM, Naderi G, Sadegh MS, Karimi A (2010) Study of garlic effect on fibrinolytic activity of the blood clot in vitro. Iran J Ped Hematol Oncol 1:18-52

17. Seo EJ, Lee D-U, Kwak JH, Lee S-M, Kim YS, Jung Y-S (2011) Antiplatelet effects of Cyperus rotundus and its component (+)nootkatone. J Ethnopharmacol 135:48-54

18. Shivasharanappa K, Londonkar R (2014) Clot lysis and antimitotic study of Ficus glomerata Roxb fruit extracts. ISRN Pharmacol 1-5

19. Haouari M, Bnouham M, Bendahou M, Aziz M, Ziyyat A, Legssyer A, Mekhfi H (2006) Inhibition of rat platelet aggregation by Urtica dioica leaves extracts. Phytother Res 20:568-572

20. Kolodziejczyk-Czepas J, Olas B, Malinowska J, Wachowicz B, Moniuszko-Szajwaj B, Kowalska I, Oleszek W, Stochmal A (2013) Trifolium pallidum and Trifolium scabrum extracts in the protection of human plasma components. J Thromb Thrombol 35:193-199

21. Kolodziejczyk-Czepas J, Wachowicz B, Moniuszko-Szajwaj B, Kowalska I, Oleszek W, Stochmal A (2013) Antioxidative effects of extracts from Trifolium species on blood platelets exposed to oxidative stress. J Physiol Biochem 69:879-887

22. Kolodziejczyk-Czepas J, Nowak P, Kowalska I, Stochmal A (2014) Biological activity of clovers-free radical scavenging ability and antioxidant action of six Trifolium species. Pharm Biol 52:1308-1314

23. Kolodziejczyk-Czepas J, Nowak P, Moniuszko-Szajwaj B, Kowalska I, Stochmal A (2015) Free radical scavenging actions of three Trifolium species in the protection of blood plasma antioxidant capacity in vitro. Pharm Biol 53:1277-1284

24. Simoncini T, Fornari L, Mannella P, Caruso A, Garibaldi S, Baldacci C, Genazzani AR (2005) Activation of nitric oxide synthesis in human endothelial cells by red clover extracts. Menopause 12:69-77

25. Lam ANC, Demasi M, James MJ, Husband AJ, Walker C (2004) Effect of red clover isoflavones on COX-2 activity in murine and human monocyte/macrophage cells. Nutr Cancer 49:89-93

26. Doolittle RF, Schubert D, Schwartz SA (1967) Amino acid sequence studies on artiodactyl fibrinopeptides: i. Dromedary camel, Mule deer, and Cape buffalo. Arch Biochem Biophys 118:456-467

27. Stochmal A, Piacente S, Pizza C, de Riccardis F, Leitz R, Oleszek W (2001) Alfalfa (Medicago sativa L.) flavonoids. Apigenin and luteolin glycosides from aerial parts. J Agric Food Chem 49:753-758

28. Wachowicz B, Kustron J (1992) Effect of cisplatin on lipid peroxidation in pig blood platelets. Cytobios 70:41-47

29. Walkowiak B, Michalak E, Koziołkiewicz W, Cierniewski CS (1989) Rapid photometric method for estimation of platelet count in blood plasma or platelet suspension. Thromb Res 56:763-766

30. Tuszynski GP, Murphy A (1990) Spectrophotometric quantitation of anchorage-dependent cell numbers using the bicinchoninic acid protein assay reagent. Anal Biochem 184:189-191

31. Wachowicz B, Olas B, Zbikowska HM, Buczynski A (2002) Generation of reactive oxygen species in blood platelets. Platelets 13:175-182 
32. Kolodziejczyk-Czepas J, Olas B, Malinowska J, Wachowicz B, Szajwaj B, Kowalska I, Oleszek W, Stochmal A (2013) Extracts from Trifolium pallidum and Trifolium scabrum aerial parts as modulators of blood platelet adhesion and aggregation. Platelets 24:136-144

33. Stegner D, Nieswandt B (2011) Platelet receptor signaling in thrombus formation. J Mol Med 89:109-121

34. Wijeyeratne YD, Heptinstall S (2011) Anti-platelet therapy: ADP receptor antagonists. Br J Clin Pharmacol 72:647-657

35. Ruggeri ZM, Mendolicchio GL (2007) Adhesion mechanisms in platelet function. Circ Res 100:1673-1685

36. Farndale RW (2006) Collagen-induced platelet activation. Blood Cell Mol Dis 36:162-165

37. Gottstein N, Ewins BA, Eccleston C, Hubbard GP, Kavanagh IC, Minihane AM, Weinberg PD, Rimbach G (2003) Effect of genistein and daidzein on platelet aggregation and monocyte and endothelial function. Brit J Nutr 89:607-615

38. Navarro-Núñez L, Rivera J, Guerrero JA, Martínez C, Vicente V, Lozano ML (2009) Differential effects of quercetin, apigenin and genistein on signalling pathways of protease-activated receptors PAR(1) and PAR(4) in platelets. Br J Pharmacol 158:1548-1556

39. Muñoz Y, Garrido A, Valladares L (2009) Equol is more active than soy isoflavone itself to compete for binding to thromboxane $\mathrm{A}(2)$ receptor in human platelets. Throm Res 123:740-744

40. di Vito C, Bertoni A, Nalin M, Sampietro S, Zanfa M, Sinigaglia F (2012) The phytoestrogen 8-prenylnaringenin inhibits agonistdependent activation of human platelets. Biochim Biophys Acta 1820:1724-1733

41. Lee DH, Kim HH, Cho HJ, Bae JS, Yu YB, Park HJ (2014) Antiplatelet effects of caffeic acid due to $\mathrm{Ca}(2+)$ mobilization inhibition via cAMP-dependent inositol-1,4,5-trisphosphate receptor phosphorylation. J Atheroscler Thromb 21:23-37

42. Wright B, Moraes LA, Kemp CF, Mullen W, Crozier A, Lovegrove JA, Gibbins JM (2010) A structural basis for the inhibition of collagen-stimulated platelet function by quercetin and structurally related flavonoids. Brit J Pharmacol 159:1312-1325

43. Park JB, Schoene N (2006) Clovamide-type phenylpropenoic acid amides, $\mathrm{N}$-coumaroyldopamine and $\mathrm{N}$-caffeoyldopamine, inhibit platelet-leukocyte interactions via suppressing P-selectin expression. J Pharmacol Exp Therap 317:813-819

44. Krenn L, Paper DH (2009) Inhibition angiogenesis and inflammation by an extract of red clover (Trifolium pratense L.). Phytomedicine 16:1083-1088

45. Sabudak T, Dokmeci D, Ozyigit F, Isik E, Aydogdu N (2008) Antiinflammatory and antioxidant activities of Trifolium resupinatum var. microcephalum extracts. Asian J Chem 20:1491-1496

46. Renda G, Yalçın FN, Nemutlu E, Akkol EK, Süntar I, Keleş H, Ina H, Çalış I, Ersöz T (2013) Comparative assessment of dermal wound healing potentials of various Trifolium L. extracts and determination of their isoflavone contents as potential active ingredients. J Ethnopharmacol 148:423-432

47. Manach C, Williamson G, Morand C, Scalbert A, Rémésy C (2005) Bioavailability and bioefficacy of polyphenols in humans. I. review of 97 bioavailability studies. Am J Clin Nutr $81: 230-242$

48. Maul R, Kulling SE (2010) Absorption of red clover isoflavones in human subjects: results from a pilot study. $\mathrm{Br} \mathrm{J}$ Nutr 103:1569-1572 